\title{
Some Physical and Mechanical Properties of Black Cumin Seeds Preparatory to Primary Processing
}

\author{
Rotimi Moses Davies \\ Department of Agricultural and Environmental Engineering, Niger Delta University, Wilberforce Island, Bayelsa State, Nigeria.
}

\author{
How to cite this paper: Rotimi Moses \\ Davies. (2021) Some Physical and Me- \\ chanical Properties of Black Cumin Seeds \\ Preparatory to Primary Processing. Engi- \\ neering Advances, 1(1), 21-25. \\ DOI: 10.26855/ea.2021.06.004 \\ Received: April 16, 2021 \\ Accepted: May 12, 2021 \\ Published: June 16, 2021 \\ *Corresponding author: Rotimi Moses \\ Davies, Department of Agricultural and \\ Environmental Engineering, Niger \\ Delta University, Wilberforce Island, \\ Bayelsa State, Nigeria. \\ Email: rotimidavies@yahoo.com
}

\begin{abstract}
The study was carried out to determine the physical, mechanical and frictional characteristics of black seeds, namely, principal axes, arithmetic mean diameter, geometric mean diameter, surface area, volume, 1000 unit mass, sphericity, aspect ratio, porosity and angle of repose bio-yield force, rupture force, compressive force and strength, modulus of elasticity of black seeds. Results showed that seeds have length, width and thickness values varied from 2.94 to $3.65 \mathrm{~mm}, 1.31$ to $2.11 \mathrm{~mm}$ and 0.62 to $1.32 \mathrm{~mm}$ respectively. The mean sphericity, aspect area, surface area, volume and 1000 unit mass of black seeds were 55\%, 47\%, 17.26 $\mathrm{mm}^{2}, 7.83 \mathrm{~mm}^{3}$ and $3.18 \mathrm{~g}$. Stainless steel surface had the lowest value of static and dynamic coefficient of friction. The positive interaction was observed between density, rupture force, yield force, yield compressive strength and significantly different at $(\mathrm{P}<0.001)$. Stainless steel is more appropriate for the construction of hopper and chute of the machine.
\end{abstract}

\section{Keywords}

Density, compressive force, principal axes, volume, friction, angle of repose

\section{Introduction}

The black seeds Nigella sativa are rich in nutritive substances and have high medicinal value. The seeds have been used in traditional medicine by many countries for instance Asia, Middle East and Egypt to treat different types of ailment such as headache, coughs, abdominal pain, diarrhea, asthma, rheumatism and other diseases [1, 2]. Many researchers have engaged in comprehensive studies of phytochemically and pharmacologically of this plant due to its medicinal and economic values [3]. The oil extracted from black seeds is rich in thymoquinone and also possess antioxidant, anti-inflammatory, anticancer, analgesic, immune booster and antimicrobial activities. Furthermore, phytochemical analyses of black cumin seeds contain more than hundreds of phytoconstituents which include majorly alkaloids, saponins, sterols and essential oil [1, 2, 4]. The (Nigella sativa L.) commonly called black seeds in English is an annual herbaceous plant and a member of Ranuculacea family [5].

The different nations of the world called the Nigella sativa seeds as: schwarzkummel (German), Hak Jung Chou (China), coriander (Romans), kalonji (Hindi/Urdu), kezah (Hebrew), chernushka (Russian), corek-out (Turkish), siyahdaneh (Persian), Kalijeera (Bangladesh), Kalonji (Indian) and carvi (French) [6]. According to Gharib-Zahed et al. [7], it described black seed as having angular shape with weight ranged between 1 and $5 \mathrm{mg}$, and also bitter tastes and peppery with a crunchy texture. The composition of the matured seeds involves moisture content ranged from $5.52 \%$ to $7.43 \%$, crude protein from $20 \%$ to $27 \%$, ash from $3.77 \%$ to $4.92 \%$, ether-extractable lipid from $34.49 \%$ to $38.72 \%$ and carbohydrates from $23.5 \%$ to $33.2 \%$ [8].

According to Yimer et al. [9], the nutritional composition of black seeds reported from different sources revealed $20 \%-85 \%$ of protein, $38.20 \%$ of fat, $7 \%-94 \%$ of fiber, and $31.94 \%$ of total carbohydrates. Takruri and Dameh [10] and Ramadan [11], observed that black cumin seed is enriched in iron, copper, zinc, phosphorus, calcium, thiamin, niacin, pyridoxine, and folic acid. Furthermore, phytochemical analyses of black seeds contain more than hundreds of phyto- 
constituents which include majorly alkaloids, saponins, sterols and essential oil. The black seed contain fixed oil (26\%-34\%), linoleic acid (64.6\%) and palmitic acid (20.4\%) [12, 13].

The information on the geometrical properties of agricultural materials is fundamental in designing machines for cleaning, sorting, grading and separation. Gravimetric characteristics are essential for the design and manufacture of machines associated with aeration, drying, storage, packaging systems and transport. The knowledge of porosity, bulk and true densities is critical in designing and manufacturing of storage capacity, air flow, drying, separating, transporting, grading and cleaning systems packaging systems, heat exchanger, transport systems and separation. The frictional characteristics for instance the angle of repose, the coefficient of static and dynamic friction are essential parameters associated with the design of grains and fruits bins and other storage structures together with the compressibility and flow behavior of biological materials.

The physical and mechanical properties have been studied for different biomaterials products by different scientists in order to develop database essential for the designing and construction of equipments for harvesting, material handling, processing, storage and packaging, such as soybean, [14] groundnut grains [15], pistachio nut and kernel, [16] cowpea [17], watermelon seed [18], shea kernel [19], cucurbit seeds [20] castor seed [21). Paucity of information on some physical and mechanical properties of black seeds which are imperative to understand the behavior of the product during processing, transporting, packaging and storage processes operations. The aim of this study was therefore to determine some the engineering characteristics of black seeds.

\section{Materials and Method}

\subsection{Sample preparation}

The black seeds (Figure 1) used for this research were purchased Ibadan, Oyo State, Nigeria. Samples were cautiously selected to avoid premature, seeds. Thus, only mature amd healthy seeds were chosen for the conduct of this experiment. This study was carried out at the moisture range of $7.6 \%$ dry basis. The moisture content of the black seeds was investigated according to ASAE [22] standard S 352.2.

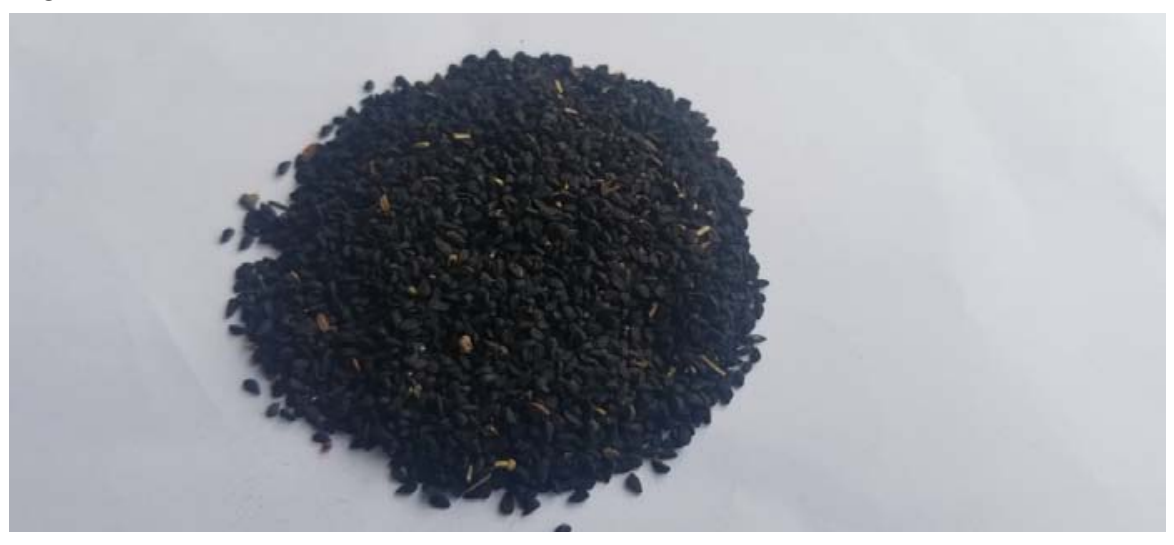

Figure 1. Black seeds.

\subsection{Geometric properties}

To determine mean of black seeds dimension, 50 seeds were randomly and carefully selected and their three linear dimensions namely, length $(L)$, width $(W)$ and thickness $(T)$ were measured using digital Vernier Caliper with an accuracy of $0.01 \mathrm{~mm}$. The mean length, width and thickness of black seeds cumin were determined using the three axial dimensions. The arithmetic mean diameter $\left(D_{a}\right)$, geometric mean diameter $\left(D_{g}\right)$, sphericity $(\Phi)$, surface area $S$, aspect ratio $R_{a}$ of black seeds were calculated by using the following relationships [16, 18, 20, 21, 23].

$$
\begin{aligned}
& \text { Da }=\frac{L+W+T}{3} \\
& \text { Dg }=(L W T)^{0.333} \\
& \text { Dsm }=\left(\frac{l W+W T+L T}{3}\right)^{0.5} \\
& \text { De }=\frac{\text { Da+Dg Dsm }}{3} \\
& \Phi=\frac{\sqrt[3]{(L W T)}}{L}
\end{aligned}
$$




$$
\begin{aligned}
& \mathrm{Ra}=\frac{\mathrm{W}}{\mathrm{L}} 100 \\
& \mathrm{As}=\frac{\pi \mathrm{B} \mathrm{L}^{2}}{(2 \mathrm{~L}-\mathrm{B})} \\
& \mathrm{V}=\frac{\pi \mathrm{B}^{2} \mathrm{~L}^{2}}{6(2 \mathrm{~L}-3)} \\
& \mathrm{B}=(\mathrm{LW})^{0.5}
\end{aligned}
$$

The volume (V) of black seeds was estimated using Davies [24]. The 1000 unit mass of black seeds determined using precision electronic balance to an accuracy of $0.01 \mathrm{~g}$. To evaluate the 1000 unit mass for fruits and nut, 50 randomly selected samples were weighed and multiplied by 20 to give the mass of 1000 seeds. The experiment was replicated ten times.

\subsection{Mechanical Properties}

The Universal Testing Machine with precision was $0.01 \mathrm{~N}$. was used for the test. Individual sample was placed on desired section and preferred speed of loading and force was applied force until it ruptured at a deformation speed of 10 $\mathrm{mm}$ min $-{ }^{1}$. The mechanical properties were determined according to Davies [24]

\section{Result and Discussion}

Some physical properties of black seeds were represented in Table 1. The length, width and thickness of black seeds varied from 2.94 to $3.65 \mathrm{~mm}, 1.31$ to $2.11 \mathrm{~mm}$ and 0.62 to $1.32 \mathrm{~mm}$ respectively. The minimum, maximum and mean arithmetic mean diameter values of black seeds were $1.62 \mathrm{~mm}, 2.36 \mathrm{~mm}$ and $1.96 \mathrm{~mm}$ respectively. The geometric mean diameter and square mean diameter were $1.77 \mathrm{~mm}$ and $1.85 \mathrm{~mm}$. The sphericity and aspect ratio of black seeds ranged between $45.37 \%$ and $55.05 \%$ and 57.81 and $44.56 \%$. Davies [25] reported the sphericity of three species of melon seeds; C. lunatus, 53\%, C. edulis, 47\% and C. vulgaris, 45\%. It was observed that black seeds will rather slide than roll based on the recommendation by Garnyak 2008 [25], that sphericity value higher than $70 \%$ is taken as spherical for grain, fruit and seed. Thus, black seed is not spherical. The mean values of sphericity as reported by Jayan and Kuman [27] for maize, red gram and cotton were $62.1 \%, 75.0 \%$ and $67.7 \%$. This property is essential in the design of hoppers and chute of a machine.

The surface area of black seeds ranged between 5.62 and $14.74 \mathrm{~mm}^{2}$. According to Davies and Mohammed [28], mentioned surface area of soursop seeds varied from $195.10 \pm 7.73 \mathrm{~mm}^{2}$ to $385.05 \pm 4.75 \mathrm{~mm}^{2}$. This is an indication that surface area of black seeds is much lower than surface area of soupsop seeds. The usefulness of this property is found in the determination of spray coverage, residues removal, rate of respiration, light reflectance and the rate of reaction during biochemical processes. The volume of black seeds varied from 7.83 to $12.50 \mathrm{~mm}^{3}$. The 1000 unit mass black seeds ranged between 2.15 and $4.02 \mathrm{~g}$.

The static coefficient of friction of black seeds against five different structural surfaces was experimented. The angle of repose was $23.6^{\circ}$ as presented in Table 2 . The mean angle of repose for maize, red gram and cotton were $22.1^{\circ}, 28.48^{\circ}$ and $21.48^{\circ}$ as reported by Jayan and Kuman [27]. The results of plywood structural surface had the highest value of static and dynamic coefficient of friction. Fiberglass surface had the lowest static coefficient friction. According to Tabatabaeefar [29], the static coefficient of friction of wheat follow similar trend. The static coefficient of friction of black seeds against five different structural surfaces was experimented. The angle of repose was $23.6^{\circ}$. The mean angle of repose for maize, red gram and cotton were $22.1^{\circ}, 28.48^{\circ}$ and $21.48^{\circ}$ was reported by Jayan and Kuman [28].

Table 1. Some physical properties of black seeds

\begin{tabular}{ccccc}
\hline Properties & No. of Samples & Maximum & Minimum & Mean \\
\hline Length (cm) & 100 & 3.65 & 2.94 & 3.24 \\
Width (cm) & 100 & 2.11 & 1.31 & 1.53 \\
Thickness (cm) & 100 & 1.32 & 0.62 & 1.12 \\
Arithmetic mean Diameter (mm) & 100 & 2.36 & 1.62 & 1.96 \\
Geometric mean Diameter (mm) & 100 & 2.17 & 1.34 & 1.77 \\
Square Mean diameter & 100 & 2.26 & 1.47 & 1.85 \\
Equilvalent Diameter & 100.00 & 2.26 & 1.48 & 1.86 \\
Sphericity (\%) & 1.00 & 59.05 & 45.37 & 55.28 \\
Aspect ratio (\%) & 100 & 57.81 & 44.56 & 47.22 \\
Surface area (mm $\left.{ }^{2}\right)$ & 100 & 14.74 & 5.61 & 9.85 \\
Volume (mm $\left.{ }^{3}\right)$ & 100 & 4.50 & 6.05 & 7.83 \\
1000-Unit mass (g) & 50 & & 2.41 & 3.18 \\
\hline
\end{tabular}


The results presented in Table 2 showed that plywood structural surface had the highest value of static and dynamic coefficient of friction. Stainless steel surface had the lowest static coefficient friction. The positive interaction were observed between density, rupture force, yield force, yield compressive strength and significantly different at $(\mathrm{P}<0.001)$ as shown in Table 3. However, density had strong negative correlation with porosity $(\mathrm{P}<0.001)$. This is an indication that all the investigated mechanical properties have strong positive interactions with each other except porosity that had negative relationship with the other properties.

Table 2. Frictional properties of black seeds

\begin{tabular}{ccc}
\hline Properties & Average & $\begin{array}{c}\text { Seeds } \\
\text { Coefficient Variation (\%) }\end{array}$ \\
\hline Angle of repose $\left(^{0}\right)$ & 23.6 & 10.76 \\
& Static coefficient & 5.43 \\
Stainless steel & 0.256 & 9.89 \\
Galvanised iron sheet & 0.342 & 10.6 \\
Plastic sheet & 0.323 & 11.4 \\
Plywood sheet & 0.387 & 9.75 \\
& Dynamic coefficient & 6.08 \\
Stainless steel & 0.219 & 7.31 \\
Galvanised iron sheet & 0.295 & 9.61 \\
Plastic sheet & 0.331 & 0.352 \\
Plywood sheet & &
\end{tabular}

Table 3. Relationship among mechanical properties variables

\begin{tabular}{|c|c|c|c|c|c|c|c|}
\hline Property & DT & $\mathrm{PO}$ & $\mathrm{RP}$ & YF & $\mathrm{BY}$ & CF & $\mathrm{MOE}$ \\
\hline DT & 1.00 & & & & & & \\
\hline $\mathrm{PO}$ & $-0.96 * * *$ & 1.00 & & & & & \\
\hline $\mathrm{RF}$ & $0.93 * * *$ & $-0.88 * * *$ & 1.00 & & & & \\
\hline YF & $0.88 * * *$ & $-0.89 * * *$ & $0.76^{* *}$ & 1.00 & & & \\
\hline BY & $0.87 * * *$ & $-0.91 * * *$ & $0.83 * *$ & $0.79 * * *$ & 1.00 & & \\
\hline CF & $0.92 * * *$ & $-0.94 * * *$ & $0.80 * *$ & $0.83 * * *$ & $0.87 * * *$ & 1.00 & \\
\hline CS & $0.95^{* * *}$ & $-0.90 * * *$ & $0.85^{* *}$ & $0.78 * * *$ & $0.75^{* * *}$ & $0.81 *$ & \\
\hline MOE & $0.90 * *$ & $-0.82 * *$ & $0.93 * *$ & $0.86^{*}$ & $0.84 *$ & $0.83 * *$ & 1.00 \\
\hline
\end{tabular}

$*=$ significant at $\mathrm{P}<0.05$, **=significant at $\mathrm{P}<0.01$, ***=significant at $\mathrm{P}<0.001$, density (DT), Porosity (PO), bioyield (BY), rupture force (RF), yield force (YF), yield compressive strength (CS), Modulus of Elasticity (MOE).

\section{Conclusion}

The physical and mechanical properties of black seeds such as length, width, thickness, arithmetic and geometric mean diameter, sphericity, surface area, 1000 unit mass, spherity, aspect ratio, rupture force, compressive force and strength were determined:

1. The length, width and the thickness of black seeds varied from 2.94 to $3.65 \mathrm{~mm}, 1.31$ to $2.11 \mathrm{~mm}$ and 0.62 to 1.32 $\mathrm{mm}$ respectively.

2. The arithmetic and geometric mean diameter and square mean diameter black seeds were 1.96, 1.77 and $1.85 \mathrm{~mm}$.

3. The mean sphericity, aspect area, surface area, volume and 1000 unit mass of black seeds were $55 \%, 47 \%, 17.26$ $\mathrm{mm}^{2}, 7.83 \mathrm{~mm}^{3}$ and $3.18 \mathrm{~g}$ respectively.

4. Plywood surface had the highest value of static and dynamic coefficient of friction.

5. The positive interaction was observed between density, rupture force, yield force, yield compressive strength and significantly different at $(\mathrm{P}<0.001)$.

\section{References}

[1] Morsi, N. M. (2000). Antimicrobial effect of crude extracts of Nigella sativa on multiple antibiotics-resistant bacteria. ActaMicrobiologica Polonica, 49, 63-74.

[2] Burits, M. and F. Bucar. (2000). Antioxidant activity of Nigellasativa essential oil. Phytotherapy Research, 14, 323-328.

[3] D’Antuono, L. F., A. Moretti, and A. F. S. Lovato. (2002). Seed yield, yield components, oil content and essential oil contentand composition of Nigella ssativa L. And Nigella damascene L. Industrial Crops and Products, 15, 59-69.

[4] Alenzi, F. Q., El-Bolkiny Yel-S., Salem, M. L. (2010). Protective effects of Nigella sativa oil and thymoquinone against toxicity induced by the anticancer drug cyclophosphamide. Br J Biomed Sci., 67: 20-28. 
[5] Hussain, D. A. S and Hussain, M. M. (2016). Nigella sativa (black seed) is an effective herbal remedy for every disease except death - a Prophetic statement which modern scientists confirm unanimously: A review. Advancement in Medicinal Plant Research, 4(2), 27-57.

[6] Khan, M. A., Chen, H., Tania, M., Zhang, D. (2011). Anticancer activities of Nigella sativa (Black Cumin). Afr J Tradit Complement Altern Med., 8(5 Suppl): 226-232.

[7] Gharib-Zahedi, T. Mousavi, T. Moayedi, S.M., Garavand, R., Alizadeh, S. M. (2010). Moisture-dependent engineering properties of black cumin (Nigellasativa L.) seed. Agric Eng Int: CIGR Journal, 1(12), 194-202.

[8] Çetin, M., Yalçin and E. Simsek, E. (2008). Some Physical and Engineering Properties of Black Cumin (Nigella sativa L.) Seed. Asian Journal of Chemistry, 4(20), 3097-3103.

[9] Yimer, E. M., Tuem, K. B., Karim, A., Ur-Rehman, N., and Anwar, F. (2019). Nigella sativa L. (Black Cumin): A Promising Natural Remedyfor Wide Range of Illnesses. Hindawi Evidence-Based Complementary and Alternative Medicine Volume 2019, Article ID 1528635, p. 16.

[10] Takruri, H. R. H. and Dameh, M. A. F. (1998). Study of the nutritional value of black cumin seeds (Nigella sativa L). Journal of the Science of Food and Agriculture, 3(76), 404-410.

[11] Ramadan, M. F. (2007). Nutritional value, functional properties and nutraceutical applications of black cumin (Nigella sativa L.): an overview. International Journal of Food Science and Technology, 10(42), 1208-1218.

[12] Mamun, M. A. and N. Absar. (2018). Major nutritional compositions of black cumin seeds cultivated in Bangladesh and the physic-ochemical characteristics of its oil. International Food Research Journal, 6(25), 2634-2639.

[13] Hala Gali-Muhtasib, N. El-Najjar R., and Schneider-Stock. (2006). The medicinal potential of black seed (Nigella sativa) and its components. Advances in Phytomedicine, 2: 2006, pp. 133-153.

[14] Davies, R. M. and EI-Okene, A. M. I. (2009). Moisture-dependent physical properties of soybean. Int. Agrophysics, 23(3): 299-303.

[15] Davies, R. M. (2009). Some physical properties of groundnut grains. Research Journal of Applied Sciences, Engineering and Technology, 1(2): 10-13.

[16] Galedar, M. N, Jafari, A., Tabatabaeefa, A. (2008). Some physical properties of wild pistachio nut and kernel as a function of moisture content. Journal of Physics and Environmental and Agricultural Sciences, 22: 117-124.

[17] Davies, R. M., Zibokere, D. S. (2011). Effects of moisture content on some physical and mechanical properties of three varieties of cowpea (vigna unguiculata (L) walp). AgricEngInt: CIGR Journal.

[18] Koocheki, A., Razavi, S. M. A., Milani, E., Moghadan, T. M., Abedini, M., Alamatiyan, S., Izadikhah, S. (2007). Physical properties of watermelon seed as a function of moisture content and variety. Int. Agrophysics, 21: 349-359.

[19] Milani, E., Razavi, S. M. A., Koocheki, A., Nikzadeh, V., Vahedi, N., MoeinFord, M., GholamhosseinPour, A. (2007). Moisture dependent physical properties of cucurbit seeds. Int.Agrophysics, 21: 157-168.

[20] Lorestani, A. N., Jaliliantabar, F., Gholami, R. (2012). Physical and mechanical properties of castor seed. Quality Assurance and Safety of Crops \& Foods, 4, 29-32.

[21] ASAE. (1998). Moisture measurement of unground grains and seeds (ASAE Standards 352.2). American Society of Agricultural Engineers.

[22] Mohsenin, N. N. (1986). Physical properties of plant and animal material. Gorgon beach science pub., Vol. 1, $483-495$.

[23] Davies. (2018). Some physical and mechanical properties of pear fruits and seeds. Int. Journal of Research Studies in Science, Engineering and Technology, 2(5), 51-57.

[24] Davies, R. M. (2009). Engineering properties of three varieties of melon seeds as potential for development of processing machine. Advance Journal of Food Sciences and Technology, 2(1): 63-66.

[25] Garnayak, D. K., Pradhan, R. C., Nalk, S. N., Bhatnagar, N. (2008). Moisture-dependent physical properties of jatropha seed. Industrial Crops Products, 27: 127-129.

[26] Jayan, N. P. R., Kuman, V. J. F. (2004). Planter design in relation to the physical properties of seeds.

[27] Davies, R. M., Mohammed, U. S. (2014). Engineering properties of bitter Kola nuts and shell as potentials for development processing machines. International Journal of Scientific Research in Environmental Sciences, 1(11): 337-343.

[28] Tabatabaeefa, A. (2003). Moisture-dependent physical properties of wheat. Int. Agrophysics, 12: 207-211. 